\title{
EXPERIMENTAL INVESTIGATION OF BUCKLING AND LATERAL TORSION BARRE INFORCED BY DELTA UNDER PURE BENDING LOAD
}

\author{
Siros Yousefi Khatoni \\ Phd Student Of Structure At University Of Urmieh, Faculty Member Of Faniherfei University, Iran
}

\begin{abstract}
Lateral torsional buckling is one of the main structural instabilityof lightweight thinmembersunder bending. In this type of structural members instability suddenly dropped considerable lateral and twisting off the page is loaded. The conventional method for preventing the occurrence of this type of buckling and lateral bracing member is using of concrete slab in the upper section. Using torsional and lateral stiffness hardening delta beams and rafters sheet resistance can beraisedand thuspreventbuckling ofthesection. In this paper, finite element program to help with difficult sections of Abaqus 6.13 Delta modeled and section capacity Delta lateral torsional buckling in front of sidereviewed studies show that optimal reinforcement to strengthen Delta is 1/4 bar height.
\end{abstract}

Keywords: experimental investigation, torsion barre, delta

\section{INTRODUCTION}

Later altorsionalbucklinginstability is one of the main structuralmembersunder bending the thinseparateentrance. In this type of structural member for instability suddenly dropped considerable lateral and twisting off thepageis loaded.In the design of Steel Moment including beam and plate girderthat of course, most of them do extensive research to improve the behavior and bending strength of these members is done.But as it stands these are lateral stability and thus the torsional and lateral buckling of them should also be considered. The conventional method for preventing the occurrence of this type of buckling and lateral bracing member or the use of concrete slab is in the upper section.AISC international conference in 1959 was expressed in the way in which they use the torsional and lateral stiffness of the Delta can be plate girder increase resistance and therefore prevent the onset of buckling point [1].

this harder connect to the flange of compressive plate girderI-shaped beams and stabilize the beam components plate girderagainst lateral torsional buckling loads arrived at the conclusion of the event they prevent [2,3].Proposed cross geometry used to be called the delta period. [1].The experimental research and computer modeling conducted on this point that the behavior of these sections are examined under different loads $[4,5,6]$. Inthisresearchistoexperimentallyloadingpure bendingand torsionalbucklingresistancetothe effect ofreinforcingthe deltaontheside.

\section{THE SPECIFICATIONS OF THE MATERIALS USED}

Profiles want to test beam score 14 (IPE14) production of steel is of the type st37. (Figure 1) 


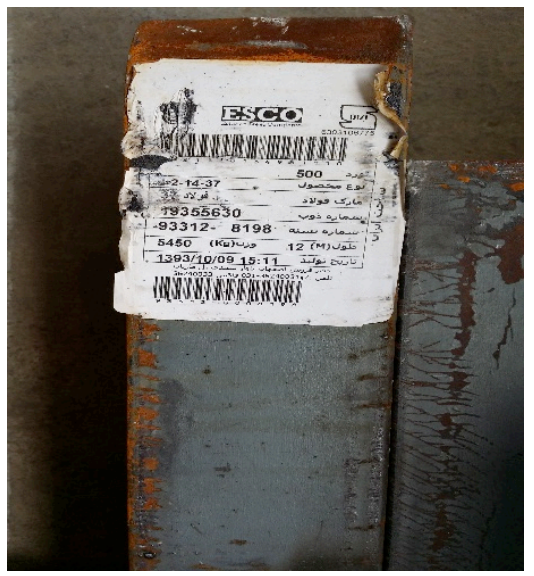

Figure 1. The 14 steel profile listed on profiles

\section{LABORATORY SAMPLE INTRODUCTION:}

Sample length is $4.5 \mathrm{~m} .75 \mathrm{~m}$ from each side as the arm anchor is intended to create momentum so that the distance between supports $3 \mathrm{~m}$ will Shdazs $\cdot \mathrm{h}$ simple example is used for testing. (Figure 2)

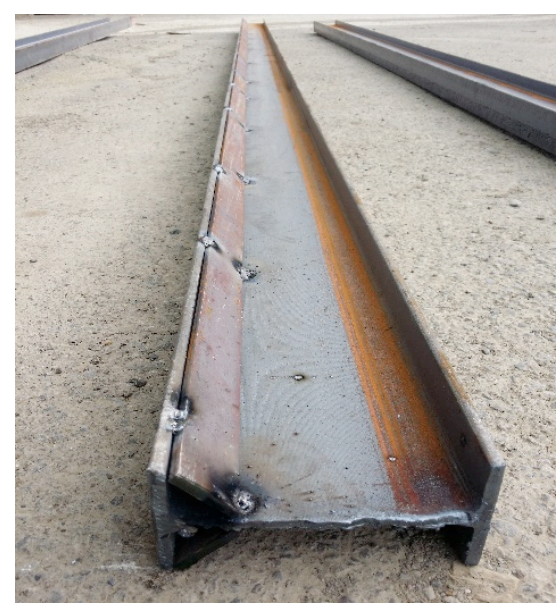

Figure 2. An example overview

\section{SAMPLES:}

All three of $4.5 \mathrm{~m}$ length and distance of load applied to the base of each side are $.75 \mathrm{~m}$.

Example 1: Example of a delta without amplification. Figure 3

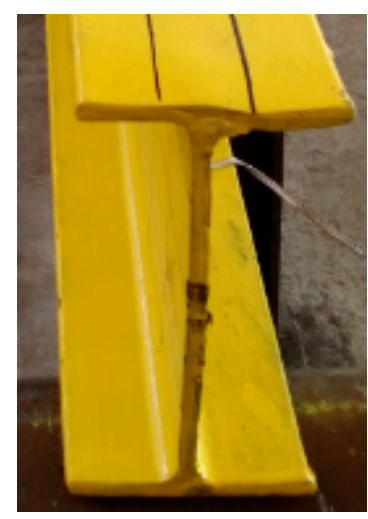

Figure 3.sampleno.1 
Example 2: An example of the strengthening of the delta and delta wings to half the height of John's location. Figure 4

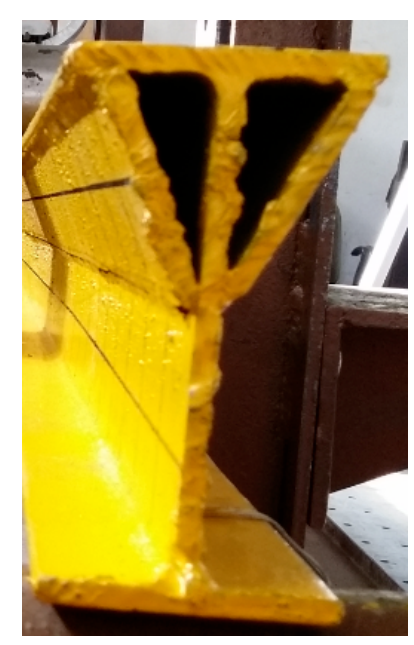

Figure 4. sampleno.2

Example 3: A typical three also by strengthening the delta and delta position of the wings up to a quarter of life is high. Figure 5

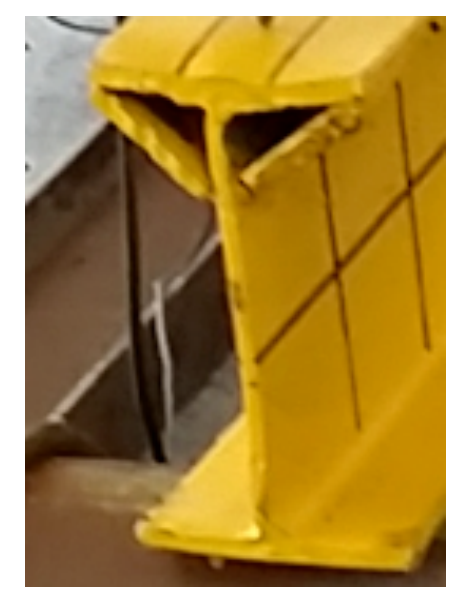

Figure 5. sampleno. 3

\section{THE THICKNESS AND THE SIZE OF PLATES USED TO DELTA:}

In the case of strip width of $6 \mathrm{~cm}$ and a thickness of $5 \mathrm{~mm}$ number two and number three of the strip width of $4.5 \mathrm{~cm}$ and a thickness of $5 \mathrm{~mm}$ is used to build the delta.

\section{The results of tests on samples:}

sample 1: Figure 6 shows the scheme of a pre-test. Jack compressive load applied by the system load by jack with lever arms to the ends of the beams inserted between two support beams under pure bending and the result is. 


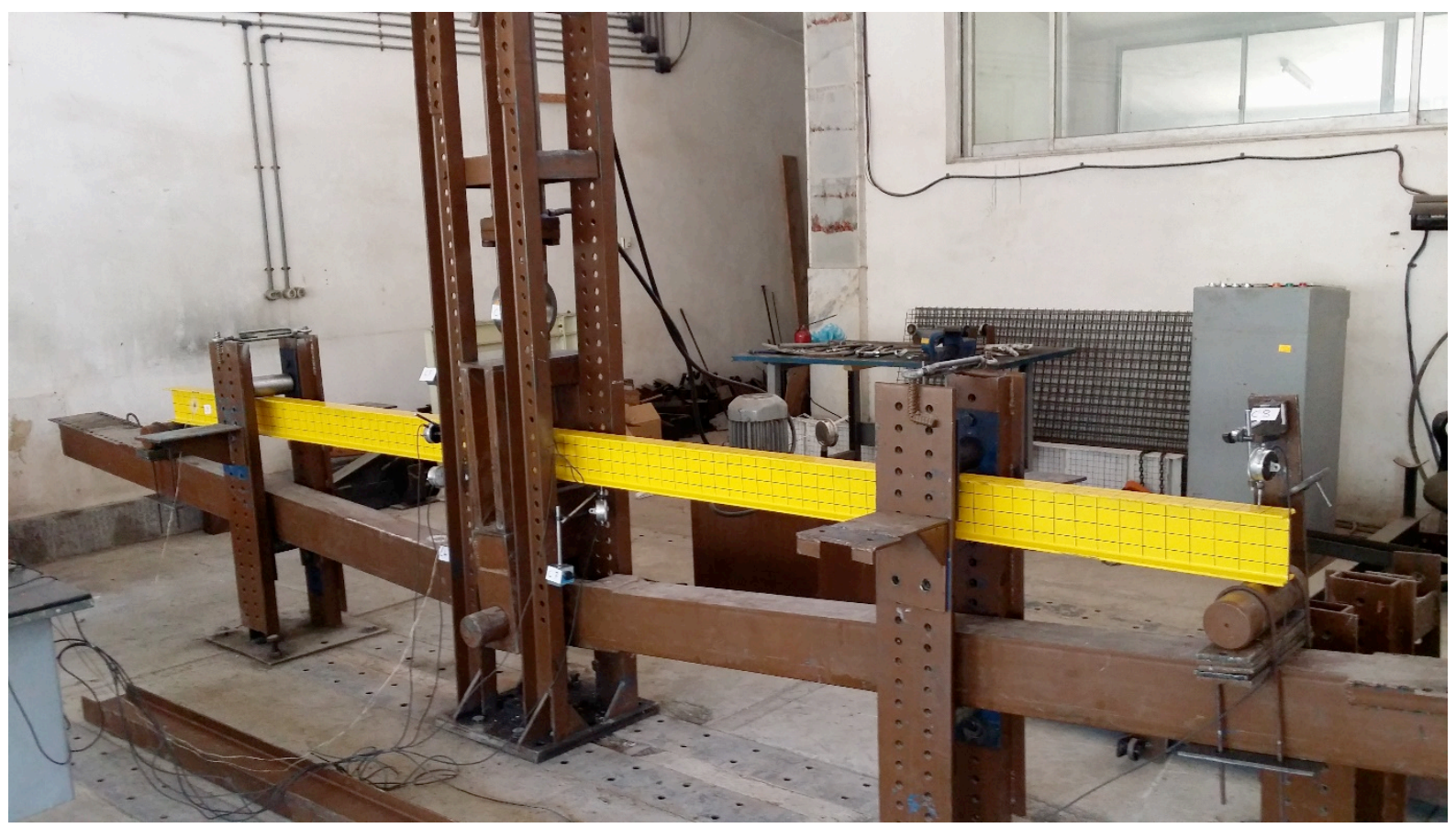

Figure 6. Example of a ride on the device before starting the test.

Figure 7 shows sample 1 after loading.

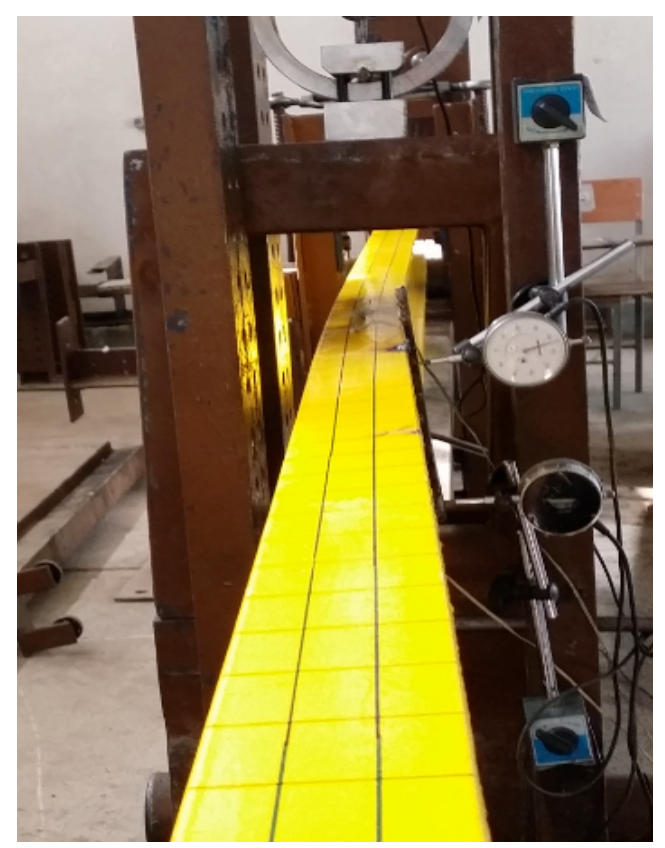

Figure 7 : sample 1 after loading

In this case, the Delta is not strengthened after loading section in the middle of the bar began to twist. The amount of time is significant. Figure 1 shows the increase during the period of increased load. 
The Turkish Online Journal of Design, Art and Communication - TOJDAC July 2016 Special Edition

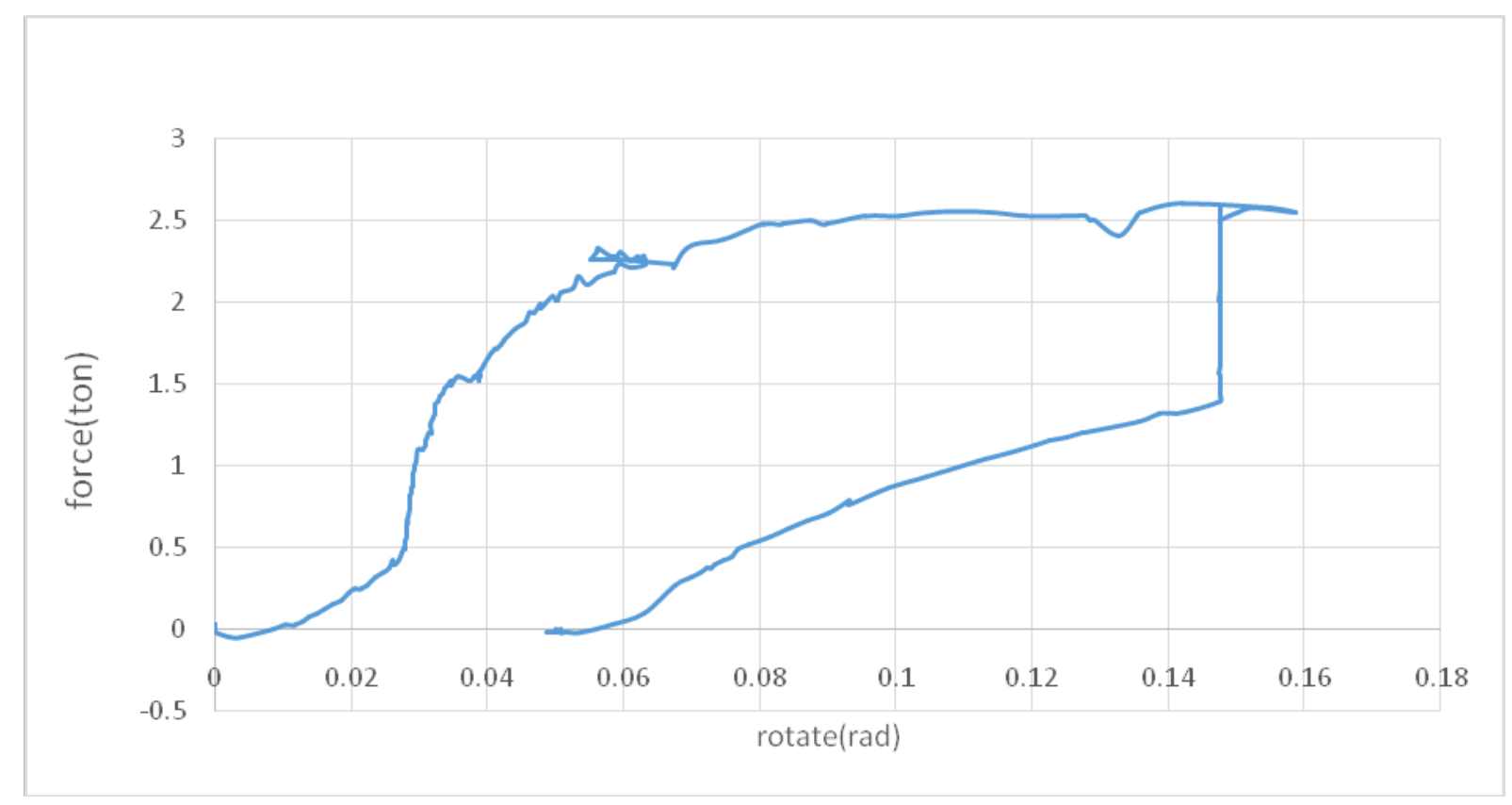

Diagram 1. Sample 1 turning point Overload

\section{Sample 2:}

Figure 8 shows the schema of two before the test.

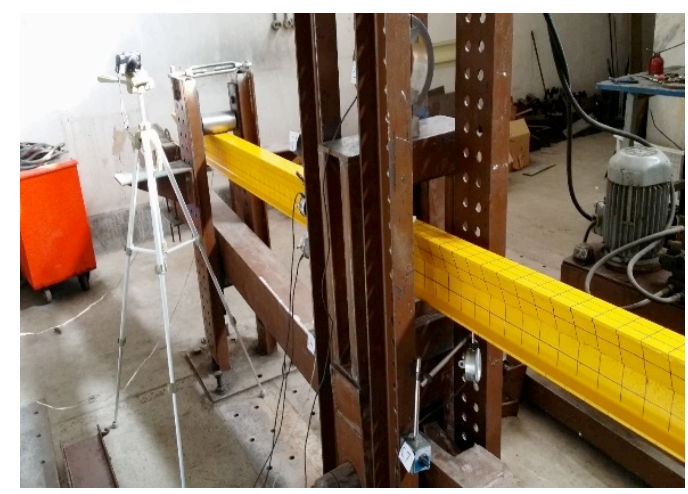

Figure 8. The sample 2 before loading

Figure 9 shows the sample two after loading. 


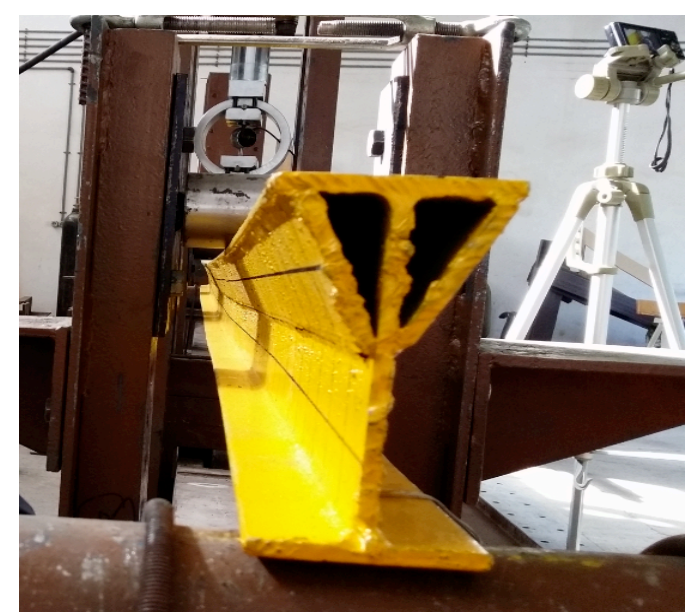

Figure 9. Typical dimensions of load (bending without buckling evident side)

In this case, which has strengthened in the middle Delta level is high at a low level compared to the amount of lateral buckling and Figure 2 shows a middle school during the shooting to the increase in times.

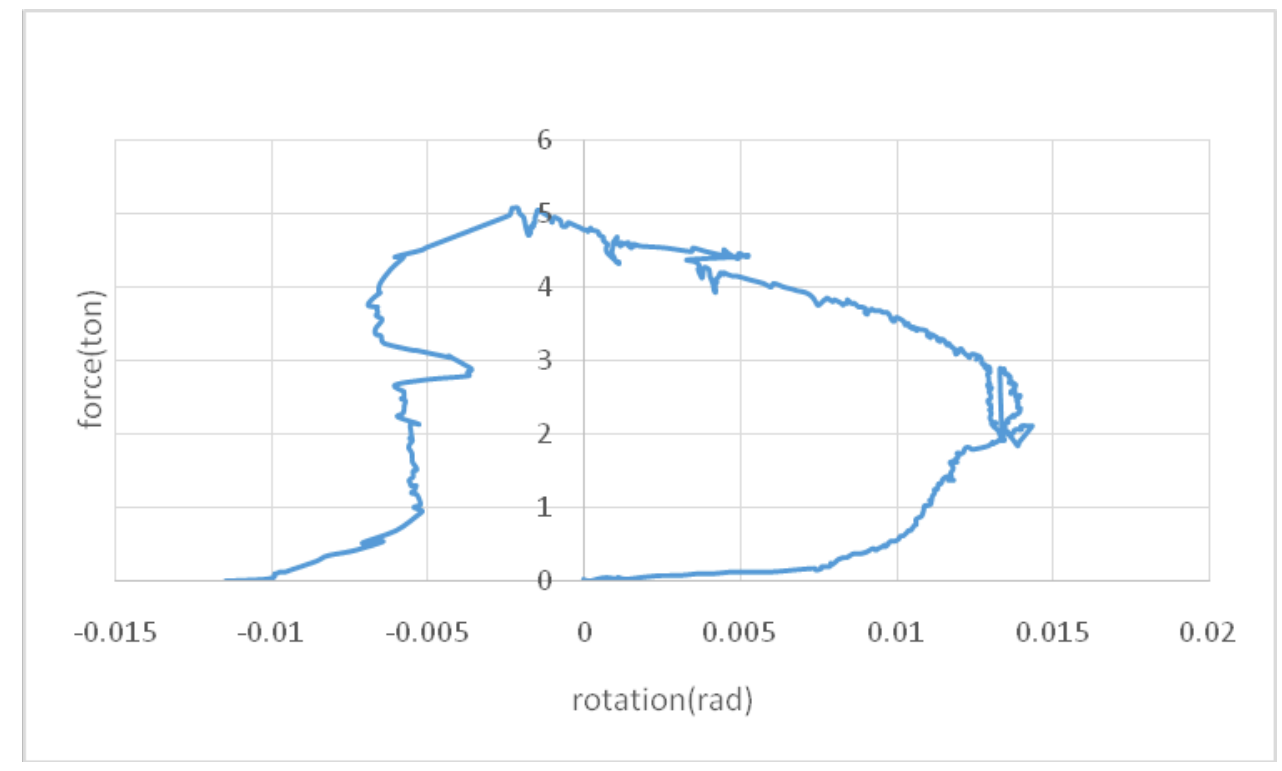

Diagram 2 during the cross-section two Overload

As can be seen from Figure 2 is negligible amounts of time compared to Figure 1 shows the boost function Delta. In example 1, the maximum period is 0.16rad while sample 2 to $0.014 \mathrm{rad}$ this maximum value is limited.

\section{sample 3:}

Figure 10 shows the sample 3 before testing. 


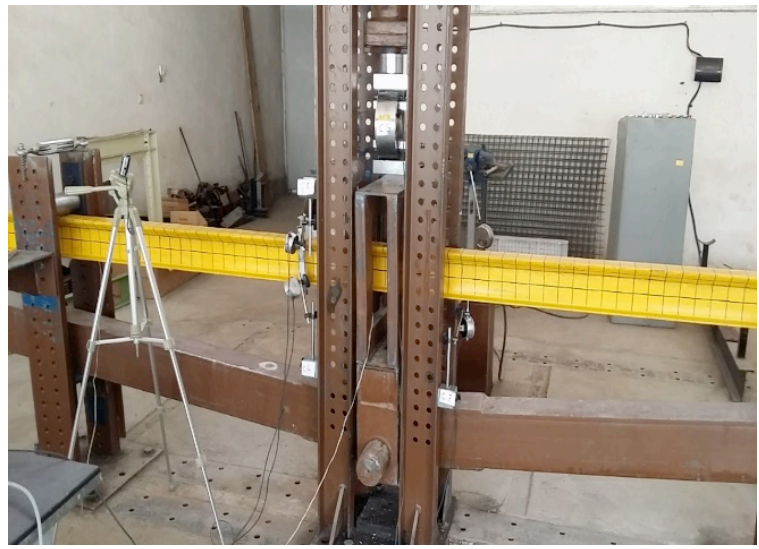

Figure 10: A typical three pre-loading

Figure 11 shows the typical three after loading.

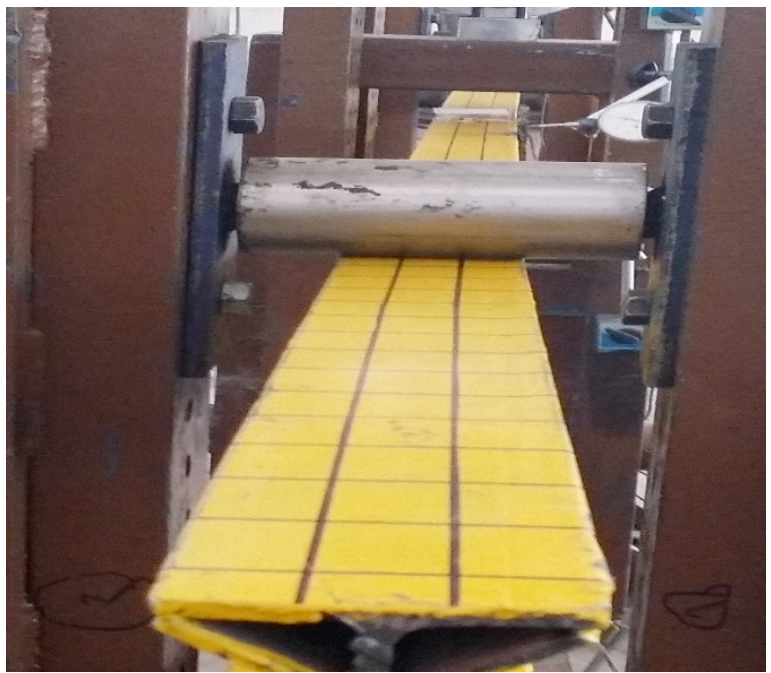

Figure 11 - sample 3 after loading

Diagram 3 shows the cross-section 3 times the applied load.

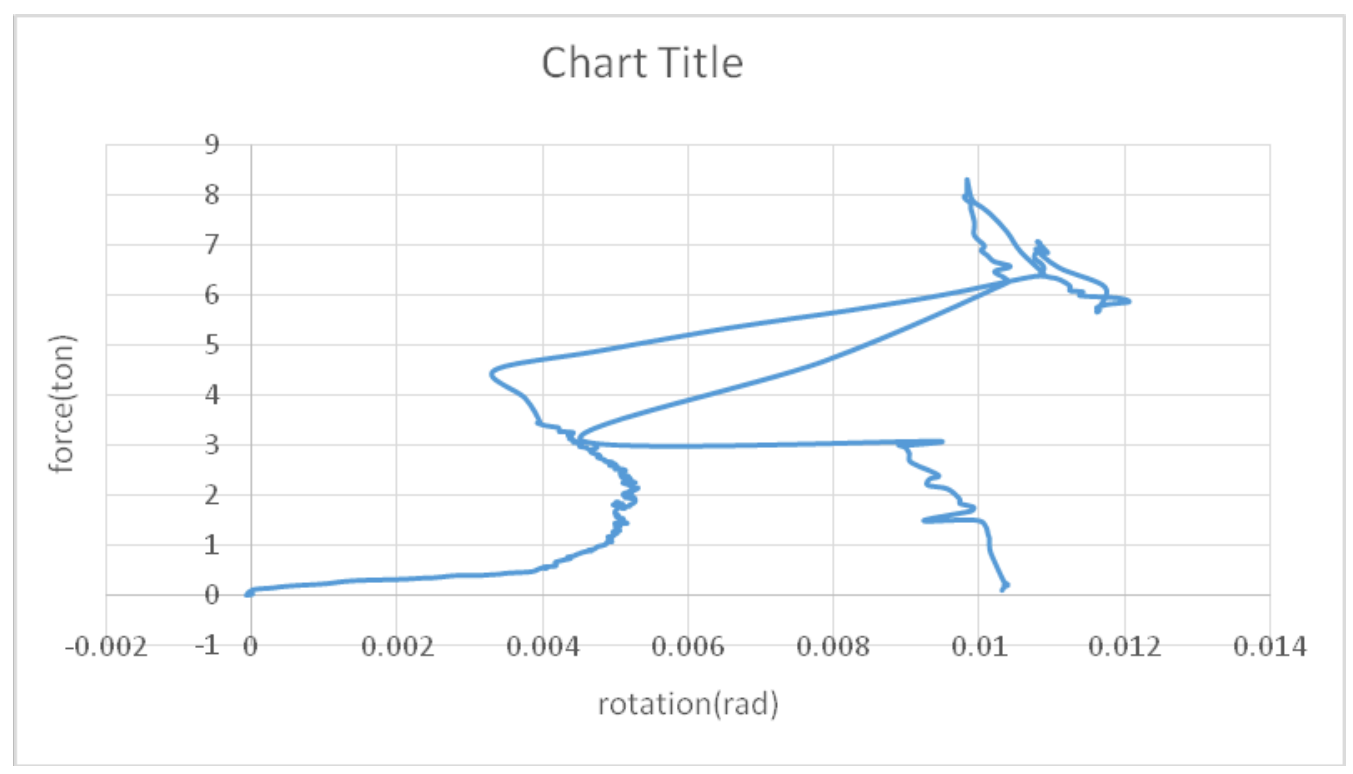


Diagram 3. The period of three in the cross section Overload

In diagram 4 the time period in all three cases have been brought together for comparison.

Unlike results anticipated period of 3 days less than the 2 shows.

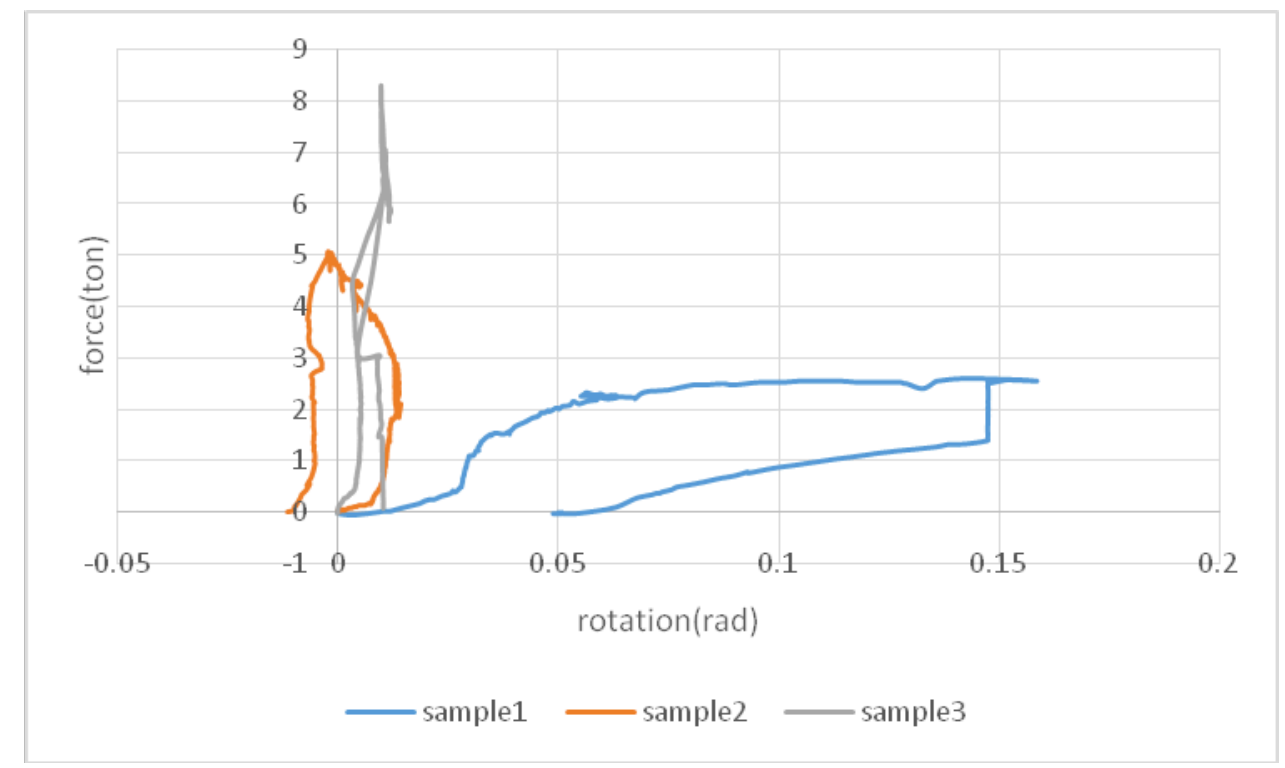

Diagram 4. During the period of total Overload

Using Abaqus analytical results are shown in Figure 5. The horizontal axis and vertical axis of rotation is the point in the middle of July the total amount of force is the anchor for comparison with experimental results.

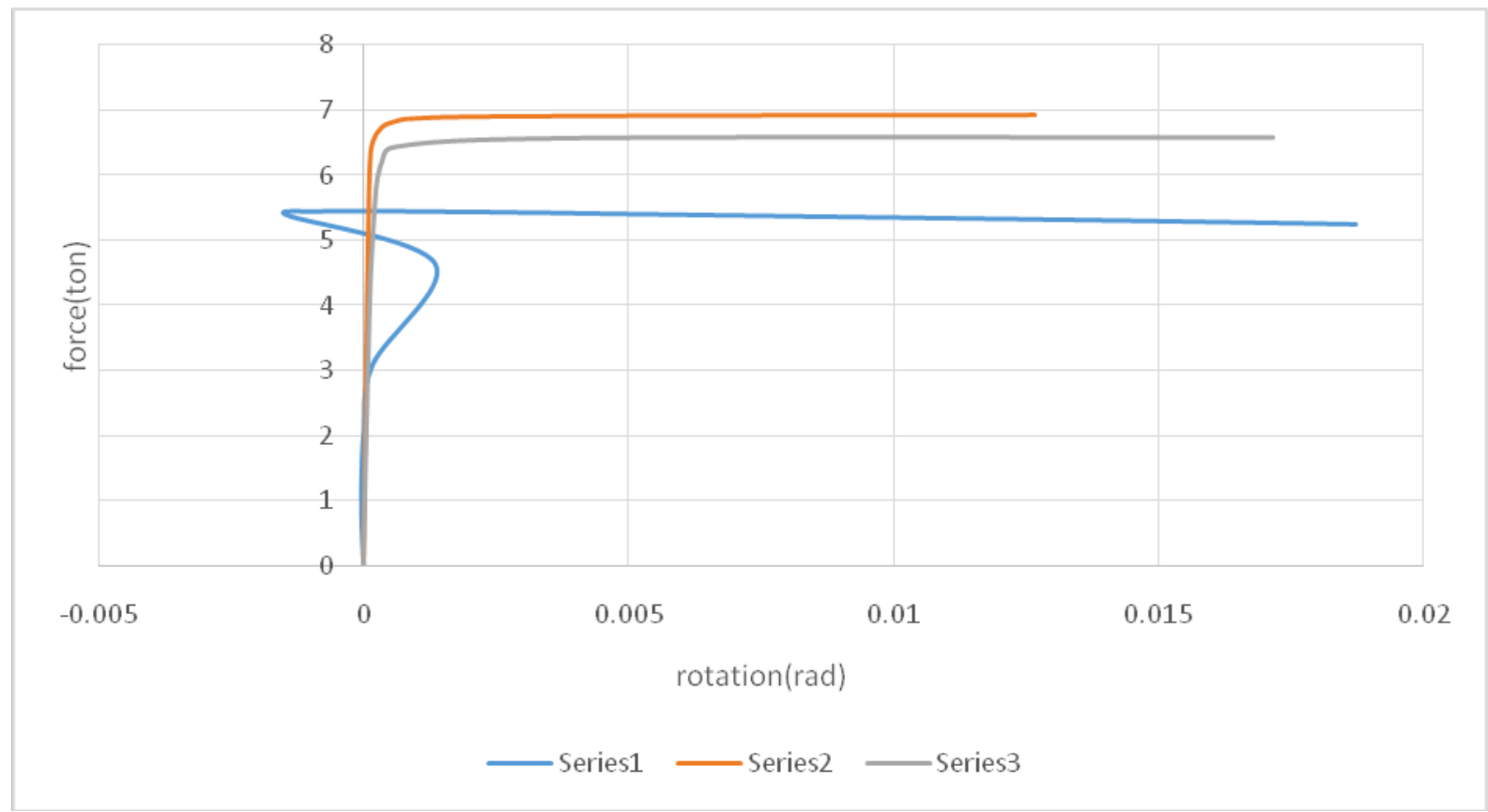

iagram 5. The results of Abaqus

The results of Abaqus also observed that the use of the Delta makes it more difficult and the side beams can be seen that the delta in fourth grade only cause a slight difference compared to the height 
of the beam height is $1 / 2$ Delta .So economically be concluded that Delta state at $1 / 4$ height is affordable.

In the form of 12 to 14 also has a buckling of the Abacus program is shown.

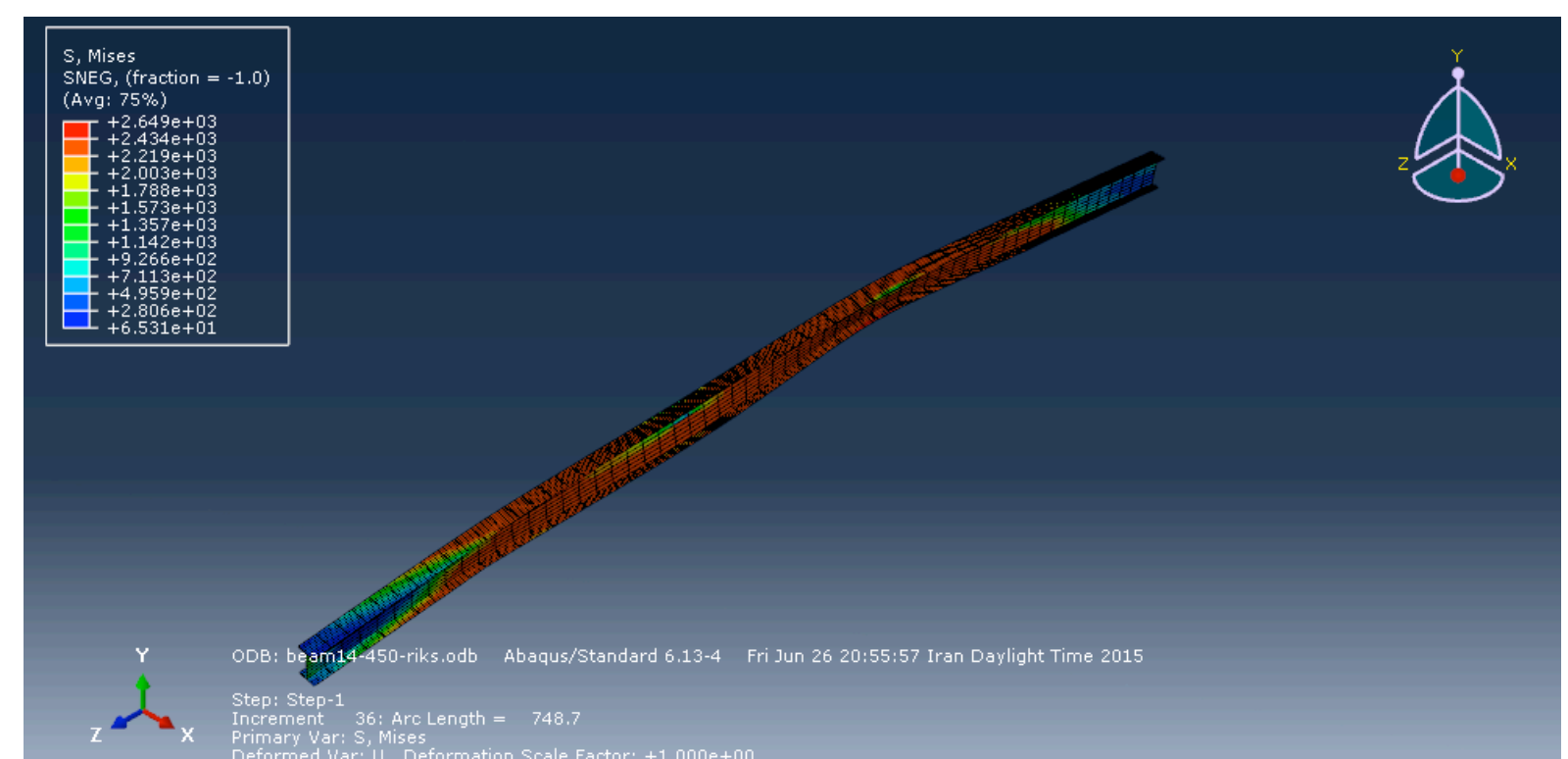

Figure 12. Deflection the beam without data

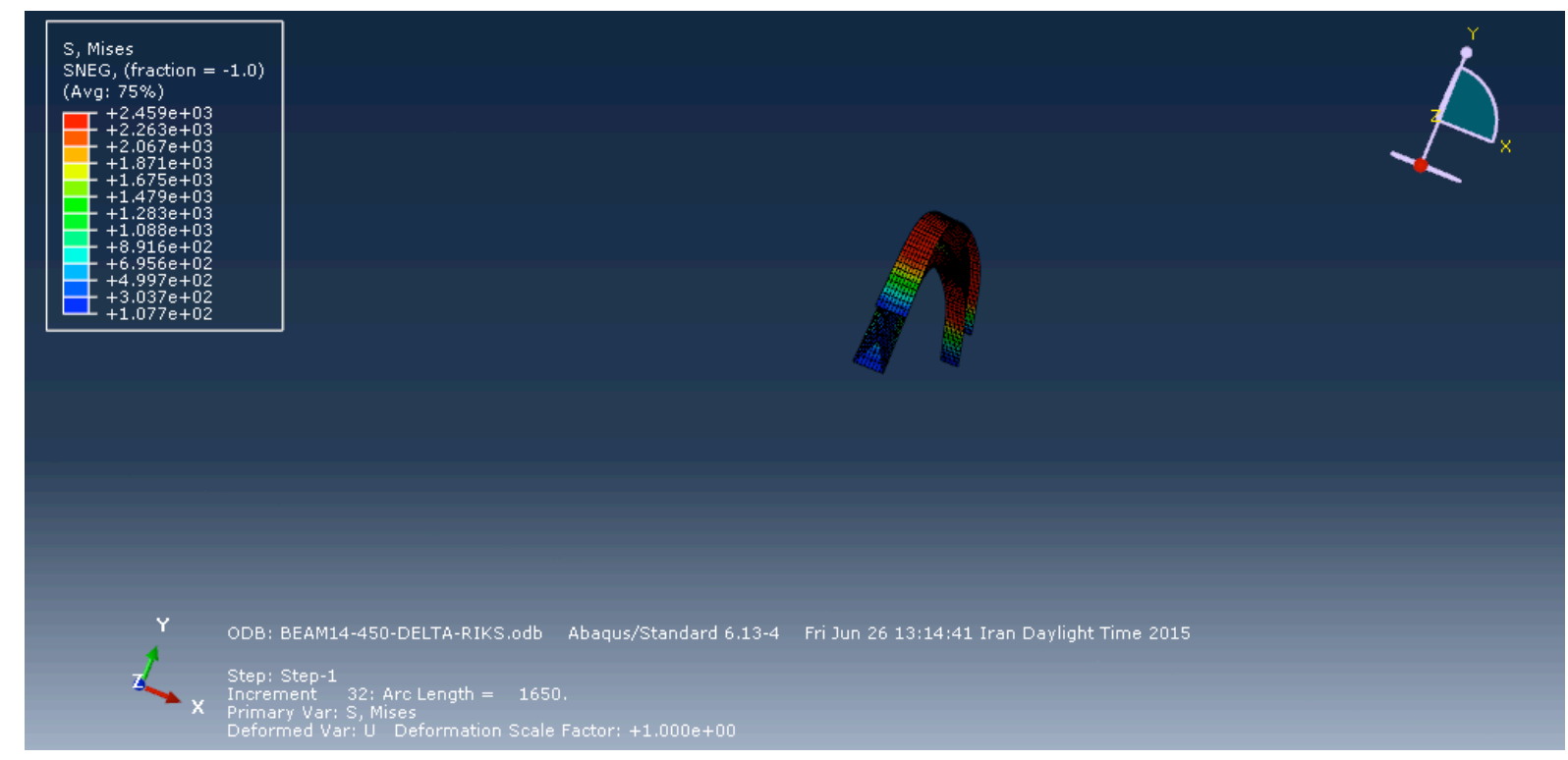

Figure 13. Delta deformed bars in $1 / 2$ beam height 
The Turkish Online Journal of Design, Art and Communication - TOJDAC July 2016 Special Edition

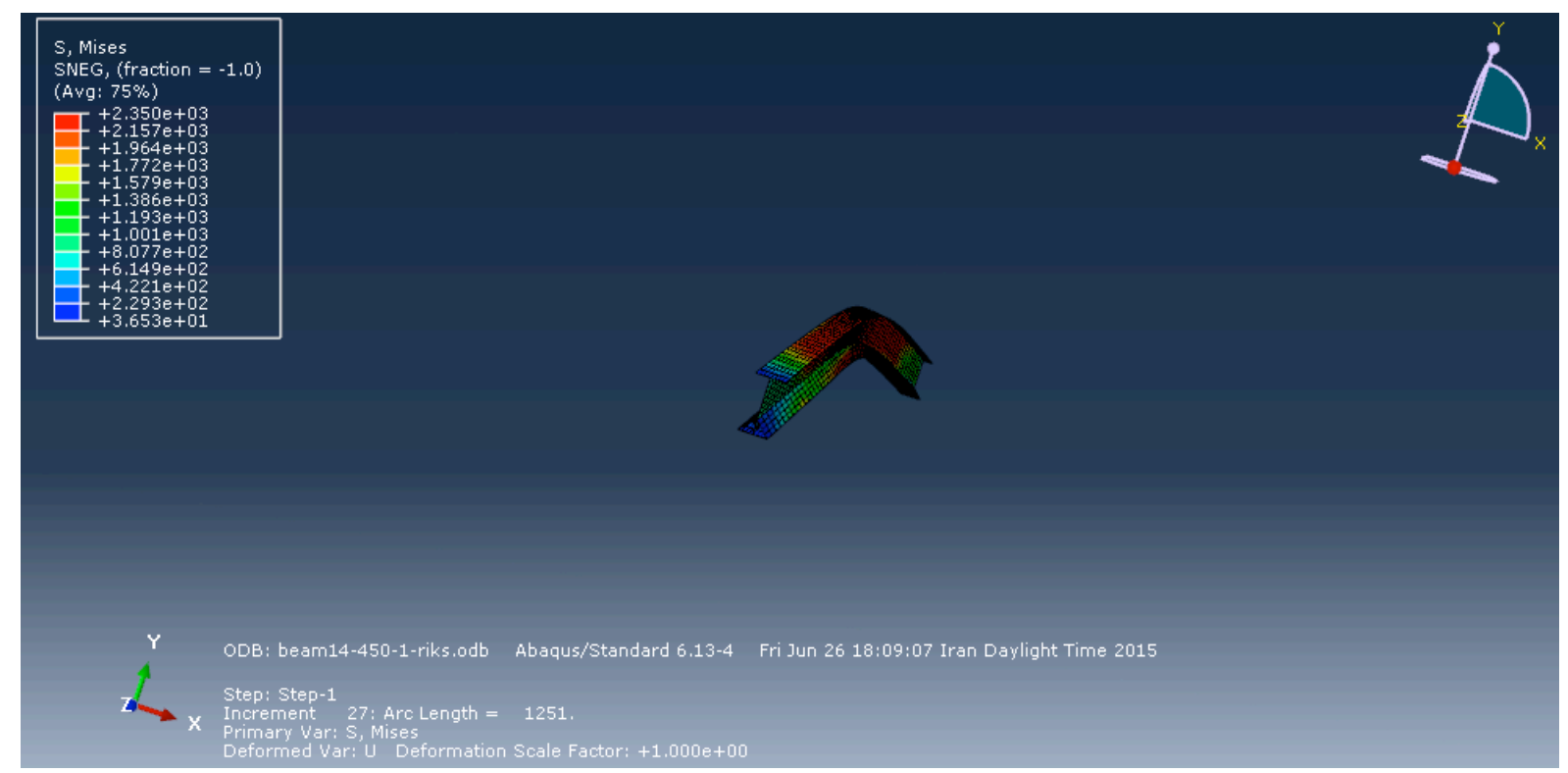

Figure 14. Delta deformed bars in $1 / 4$ beam height

Moreover, the results derived from the output parameters examined samples brought.

sample 1: No data

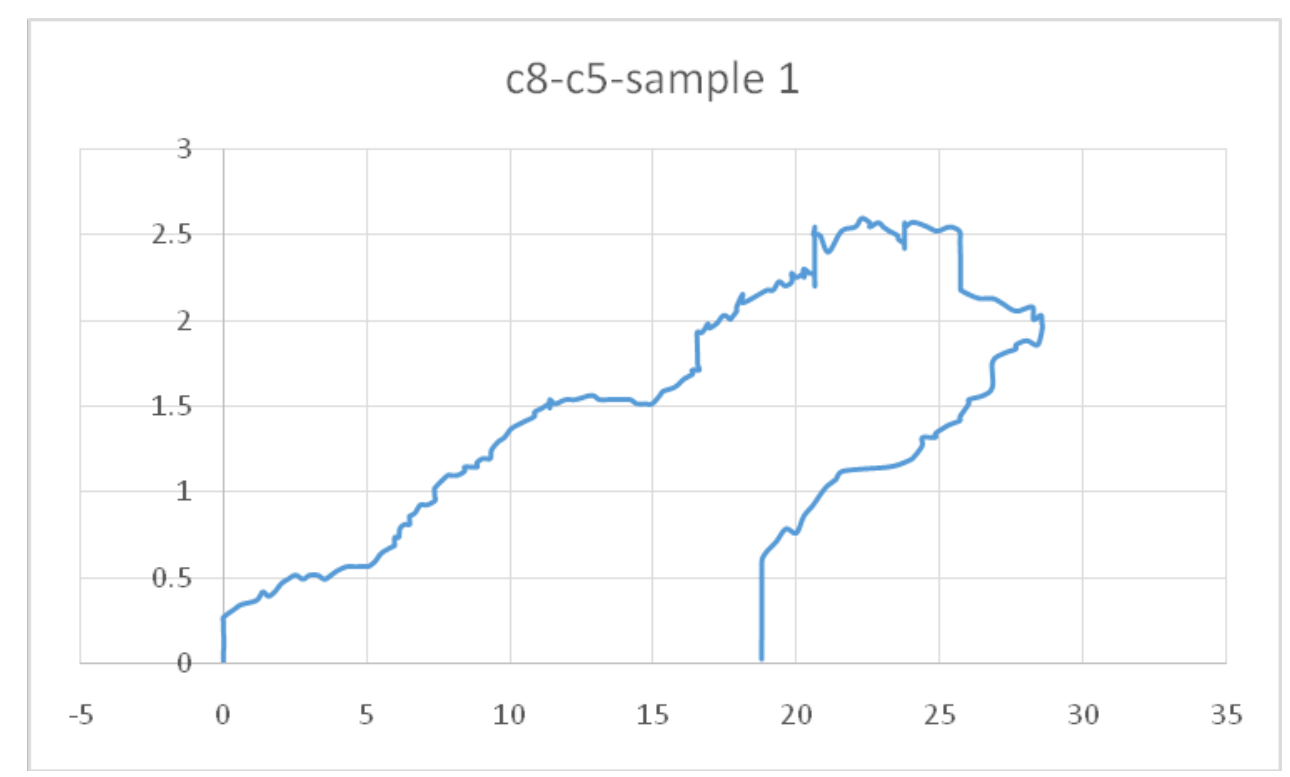


The Turkish Online Journal of Design, Art and Communication - TOJDAC July 2016 Special Edition
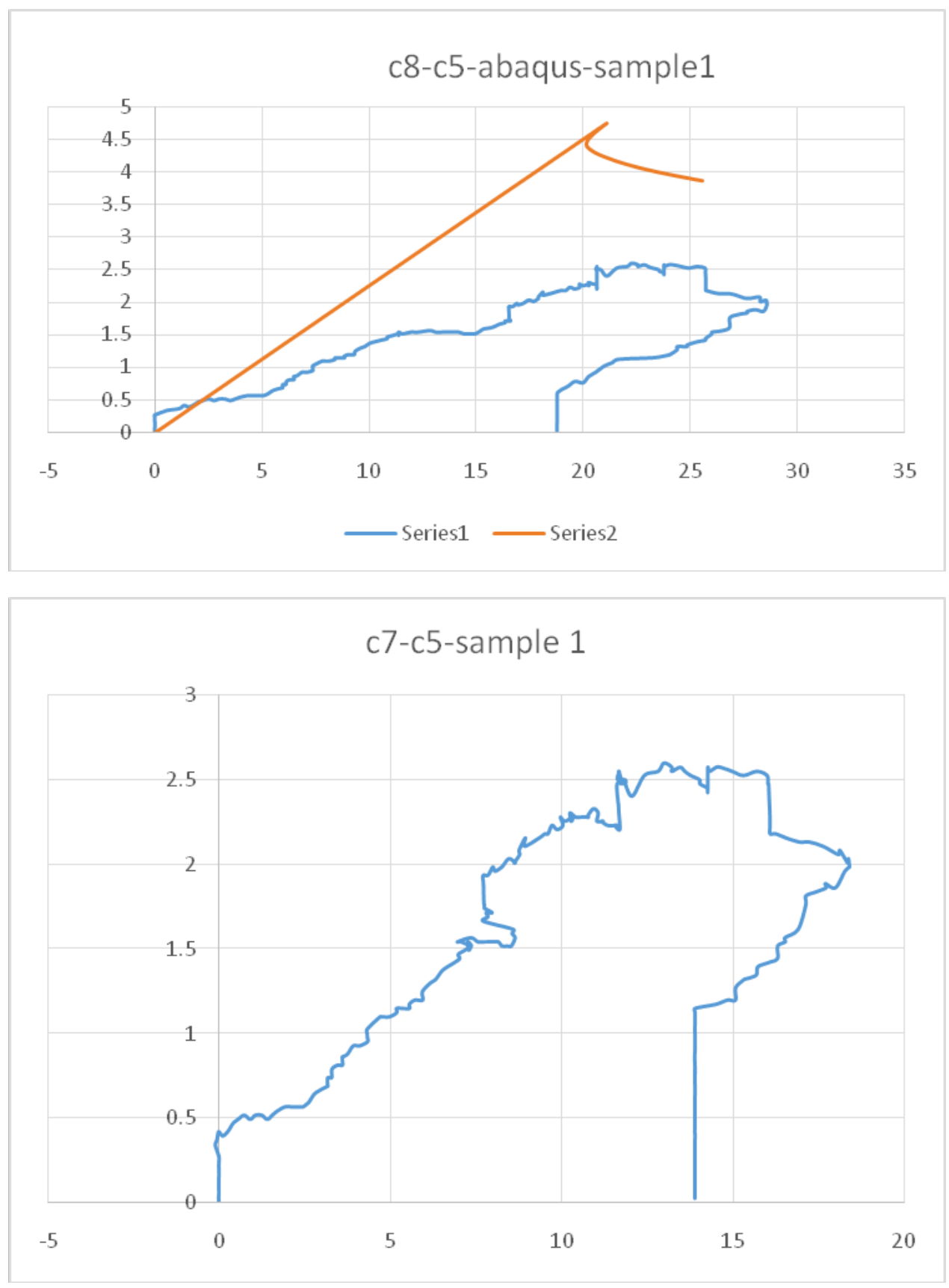
The Turkish Online Journal of Design, Art and Communication - TOJDAC July 2016 Special Edition
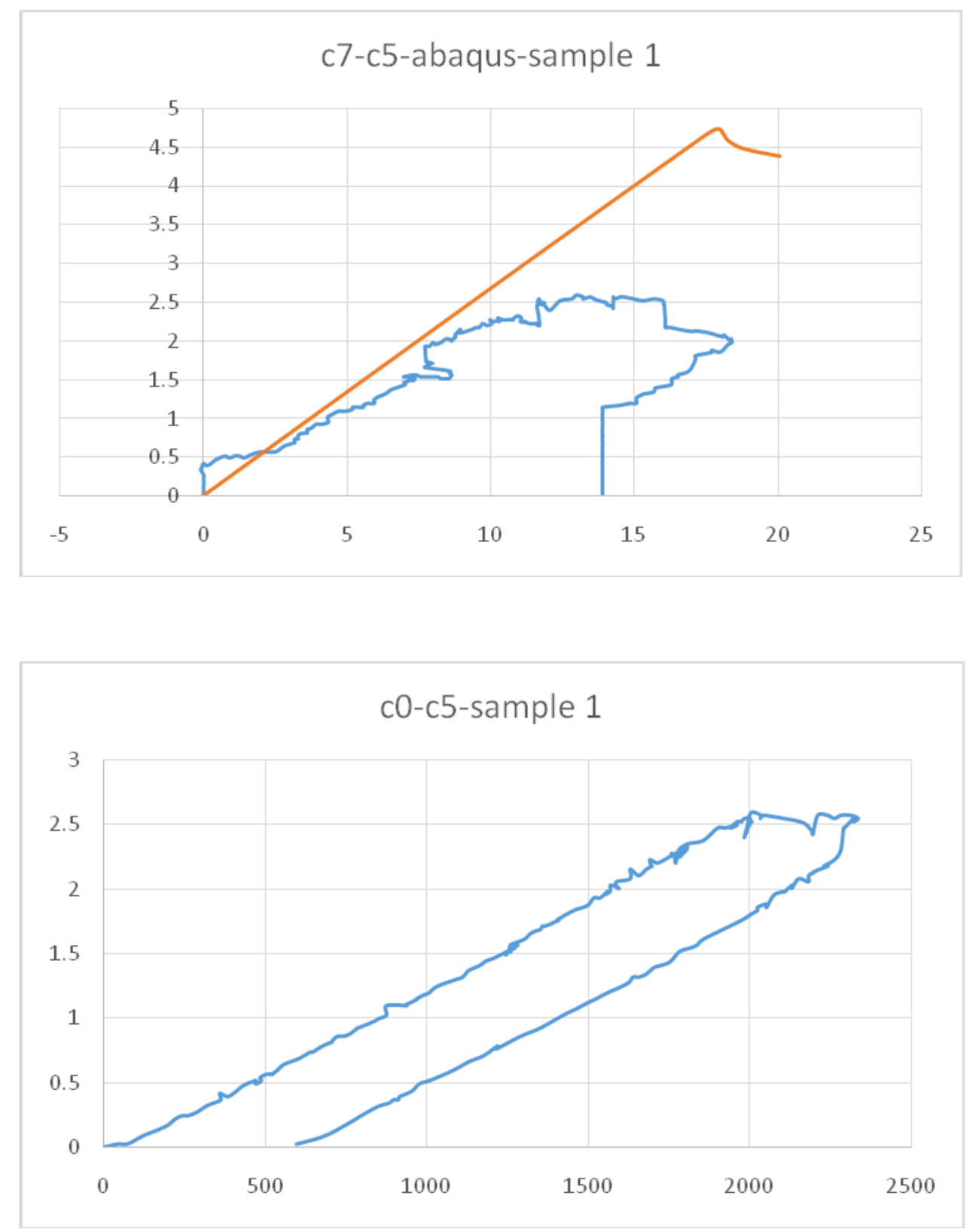
The Turkish Online Journal of Design, Art and Communication - TOJDAC July 2016 Special Edition
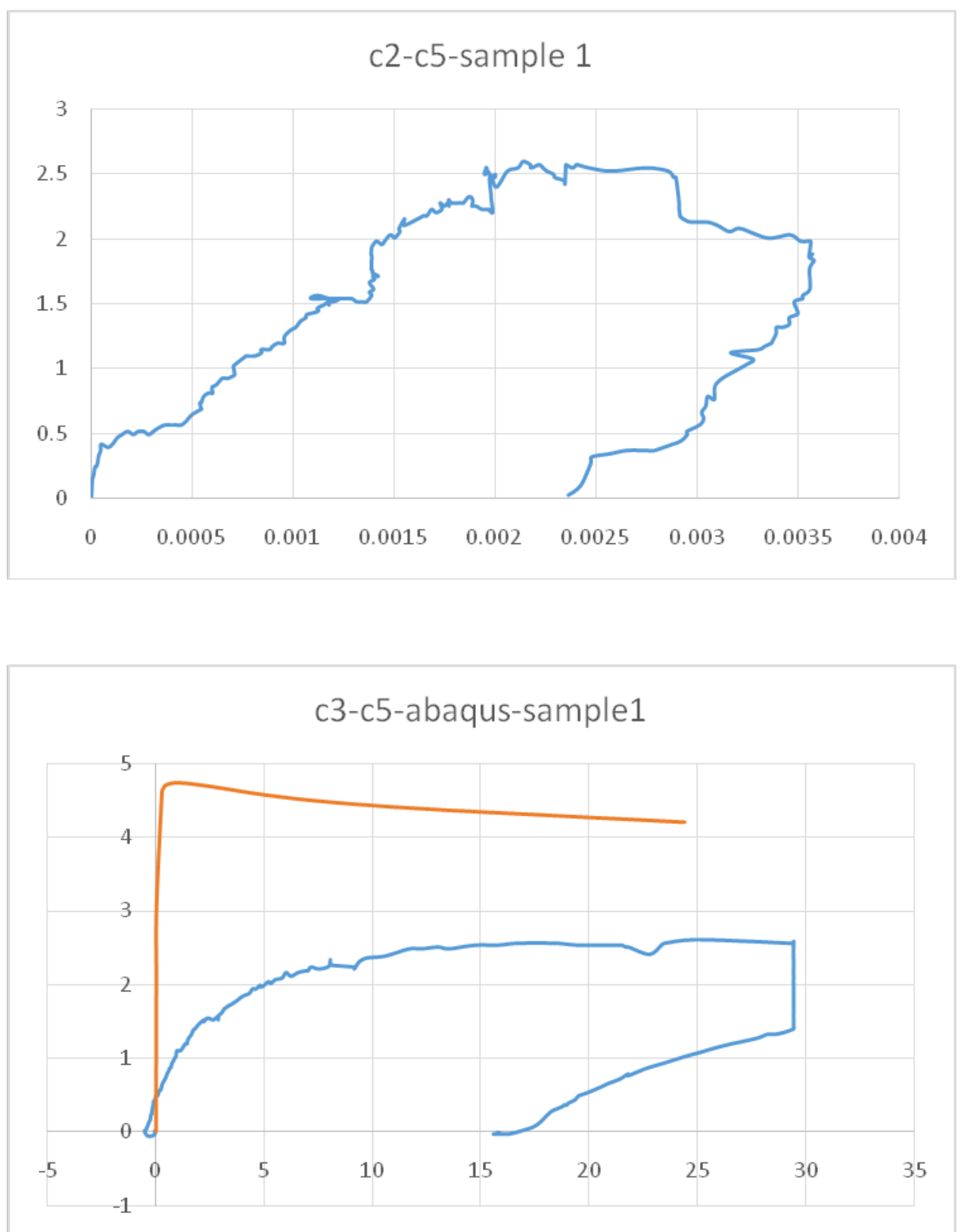
The Turkish Online Journal of Design, Art and Communication - TOJDAC July 2016 Special Edition
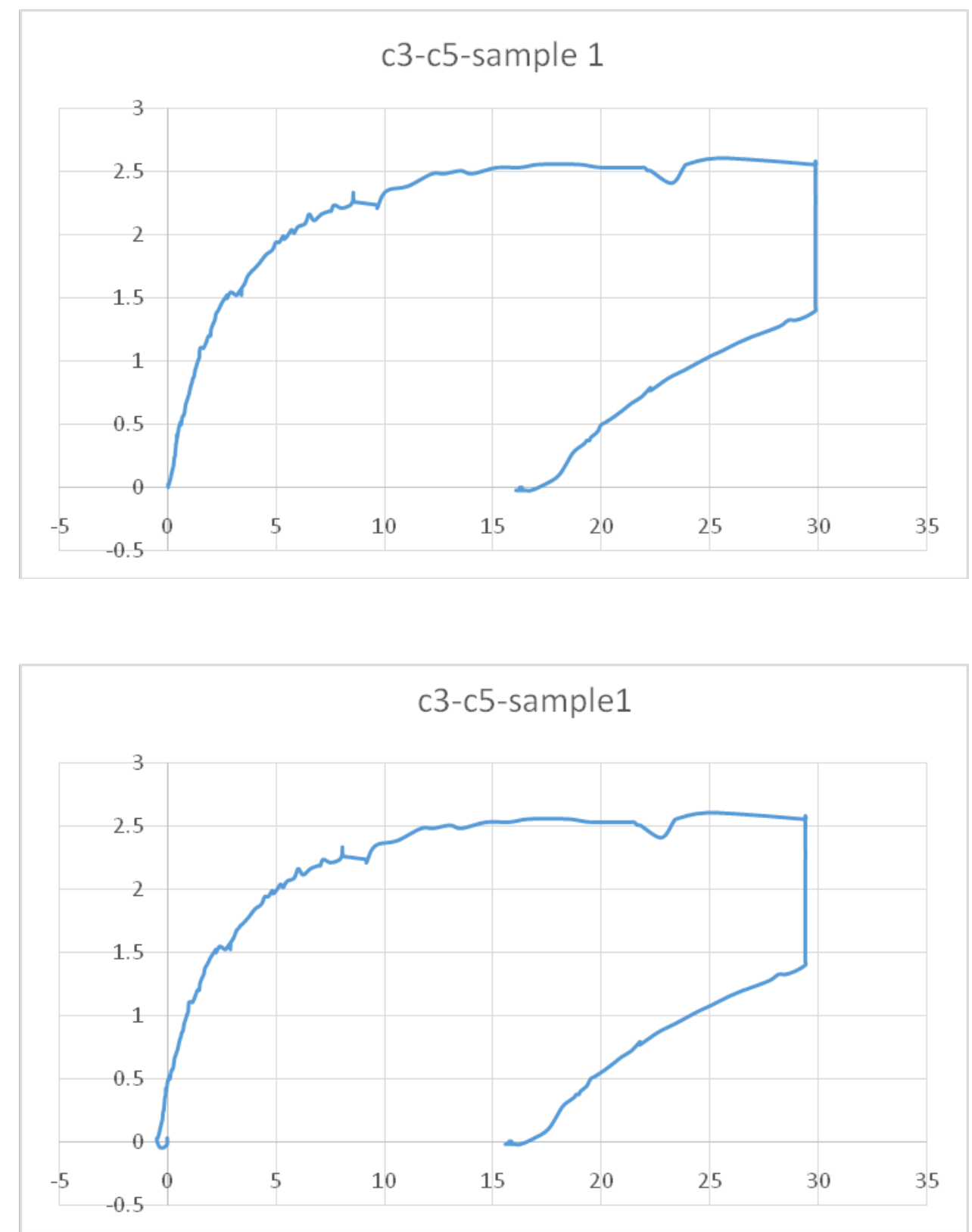
The Turkish Online Journal of Design, Art and Communication - TOJDAC July 2016 Special Edition

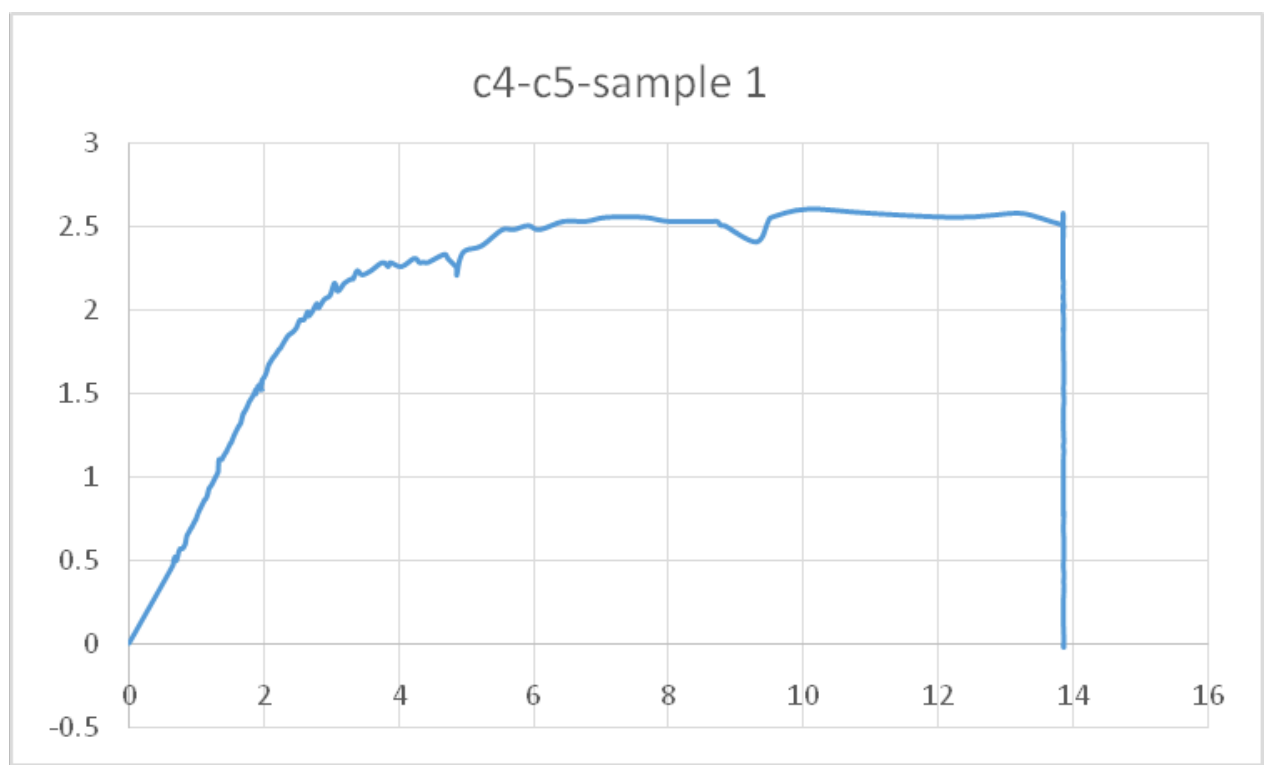

sample2: delta sample at half height

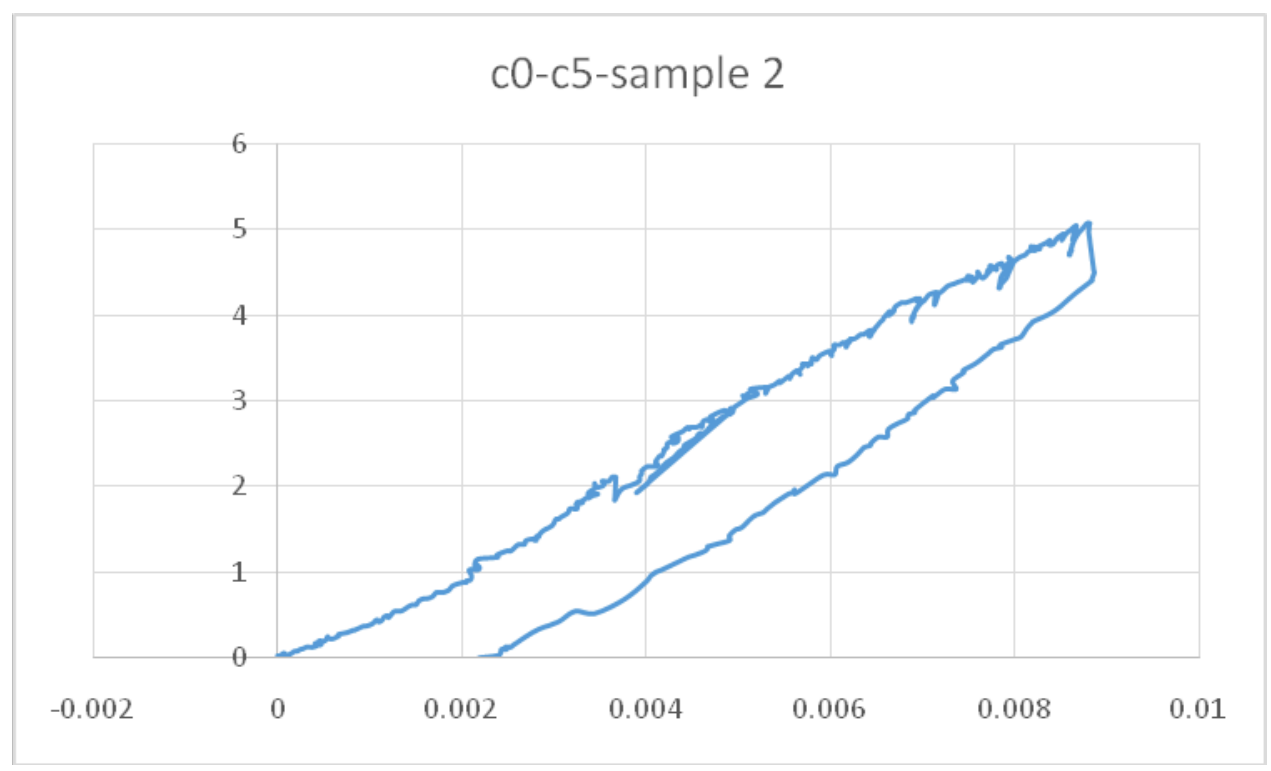


The Turkish Online Journal of Design, Art and Communication - TOJDAC July 2016 Special Edition
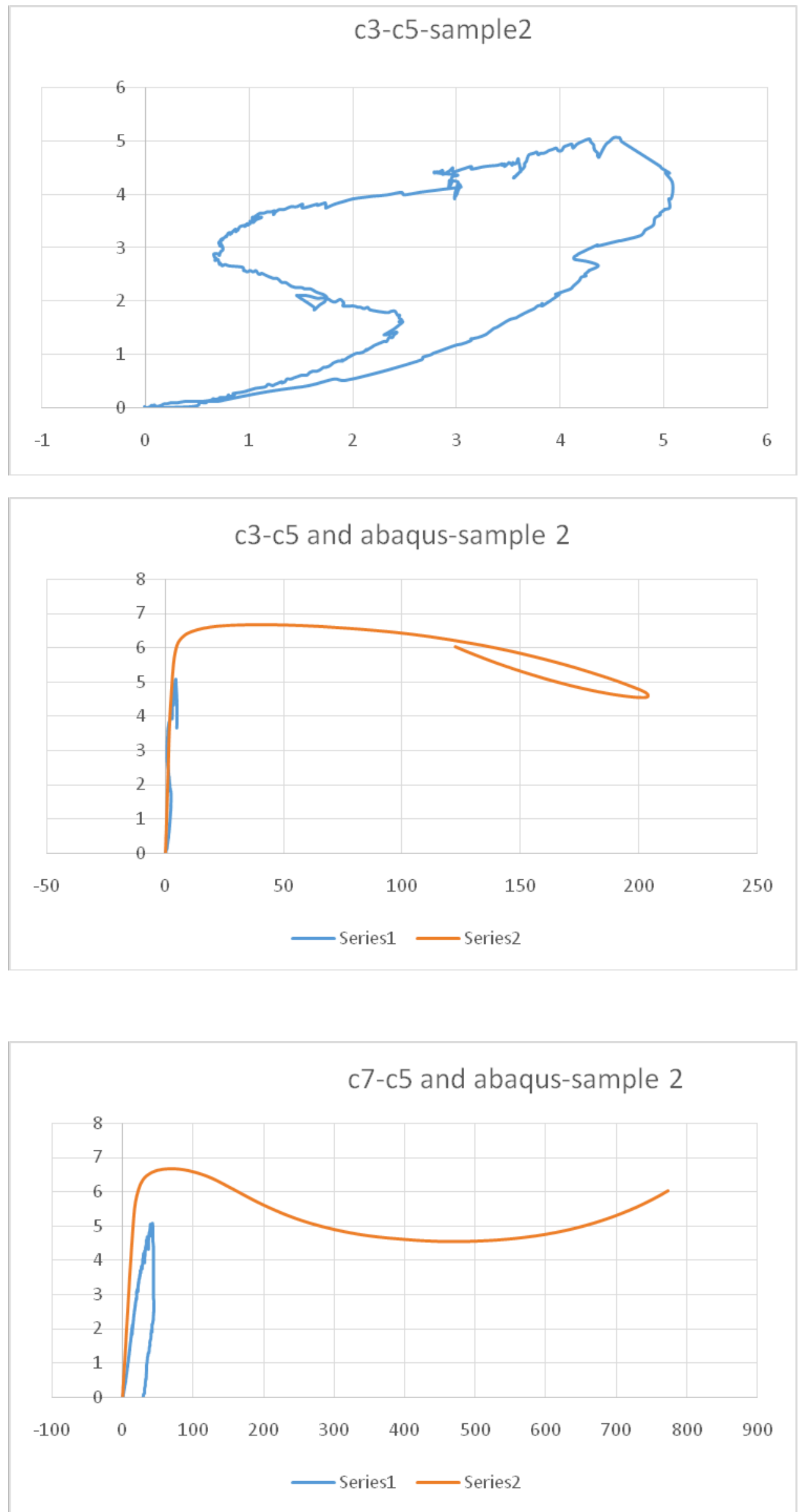

Submit Date: 01.05.2016, Acceptance Date: 10.06.2016, DOI NO: 10.7456/1060JSE/050 Copyright (C) The Turkish Online Journal of Design, Art and Communication 
The Turkish Online Journal of Design, Art and Communication - TOJDAC July 2016 Special Edition
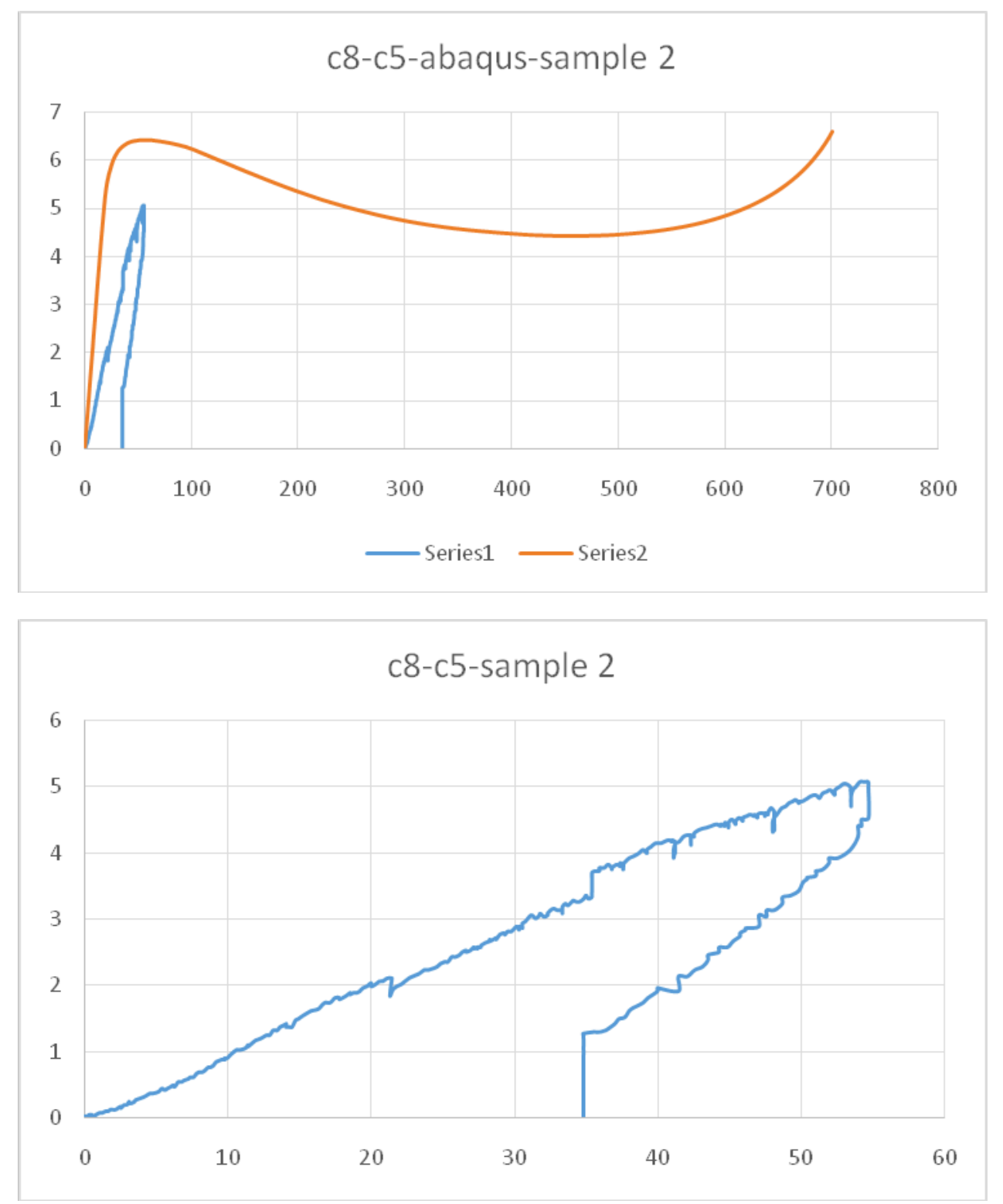
The Turkish Online Journal of Design, Art and Communication - TOJDAC July 2016 Special Edition

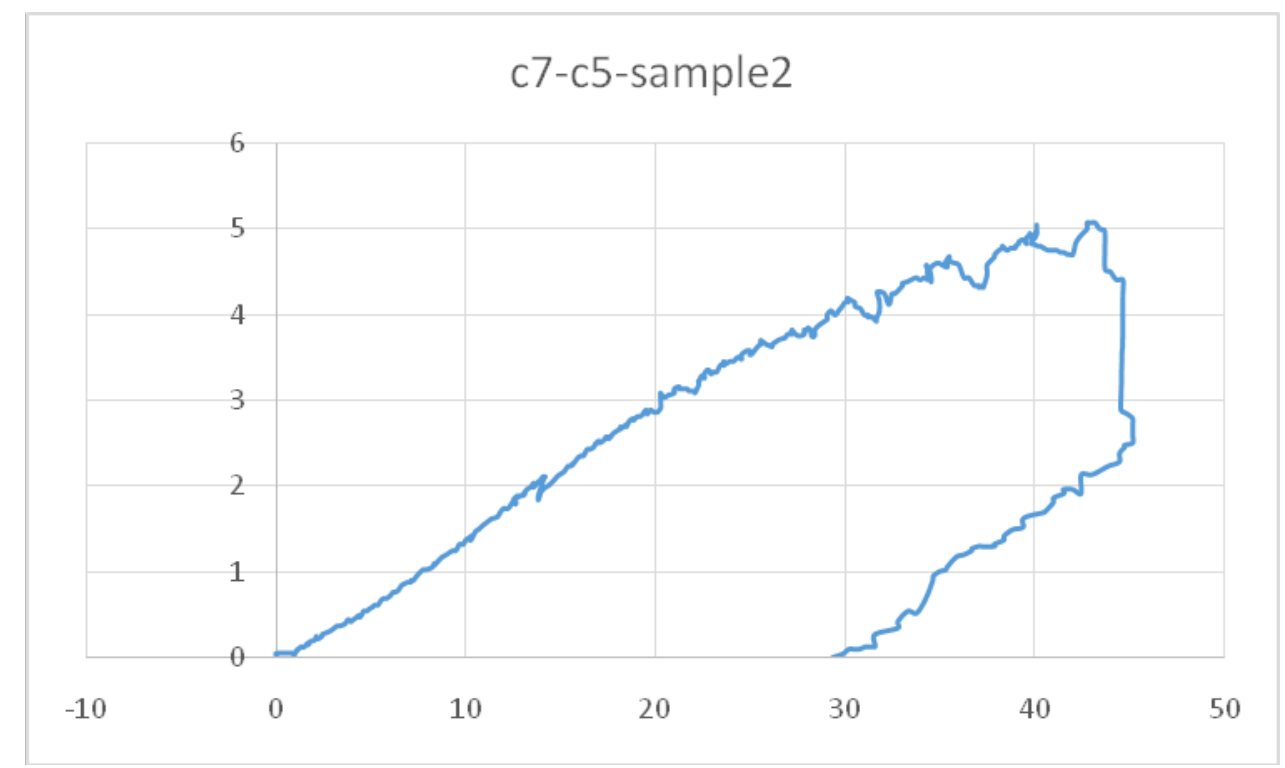

sample 3: Delta in the quarter-height

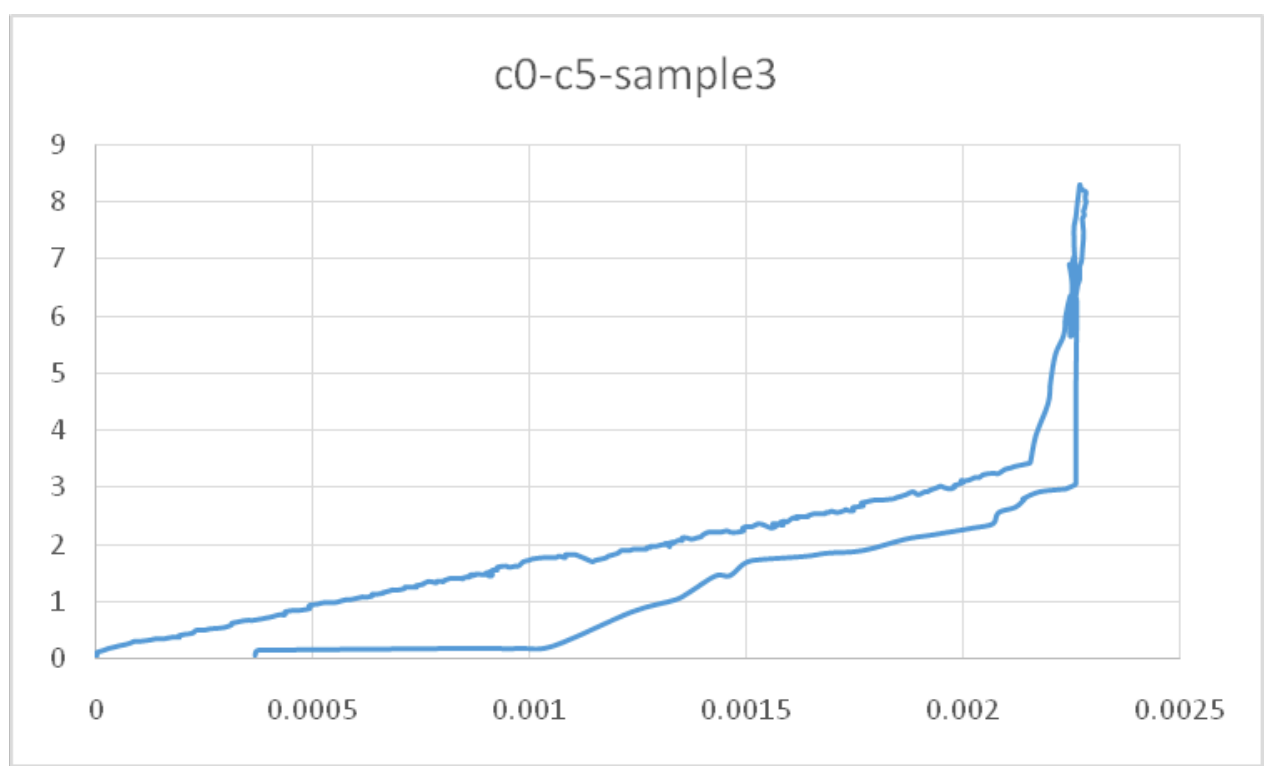


The Turkish Online Journal of Design, Art and Communication - TOJDAC July 2016 Special Edition
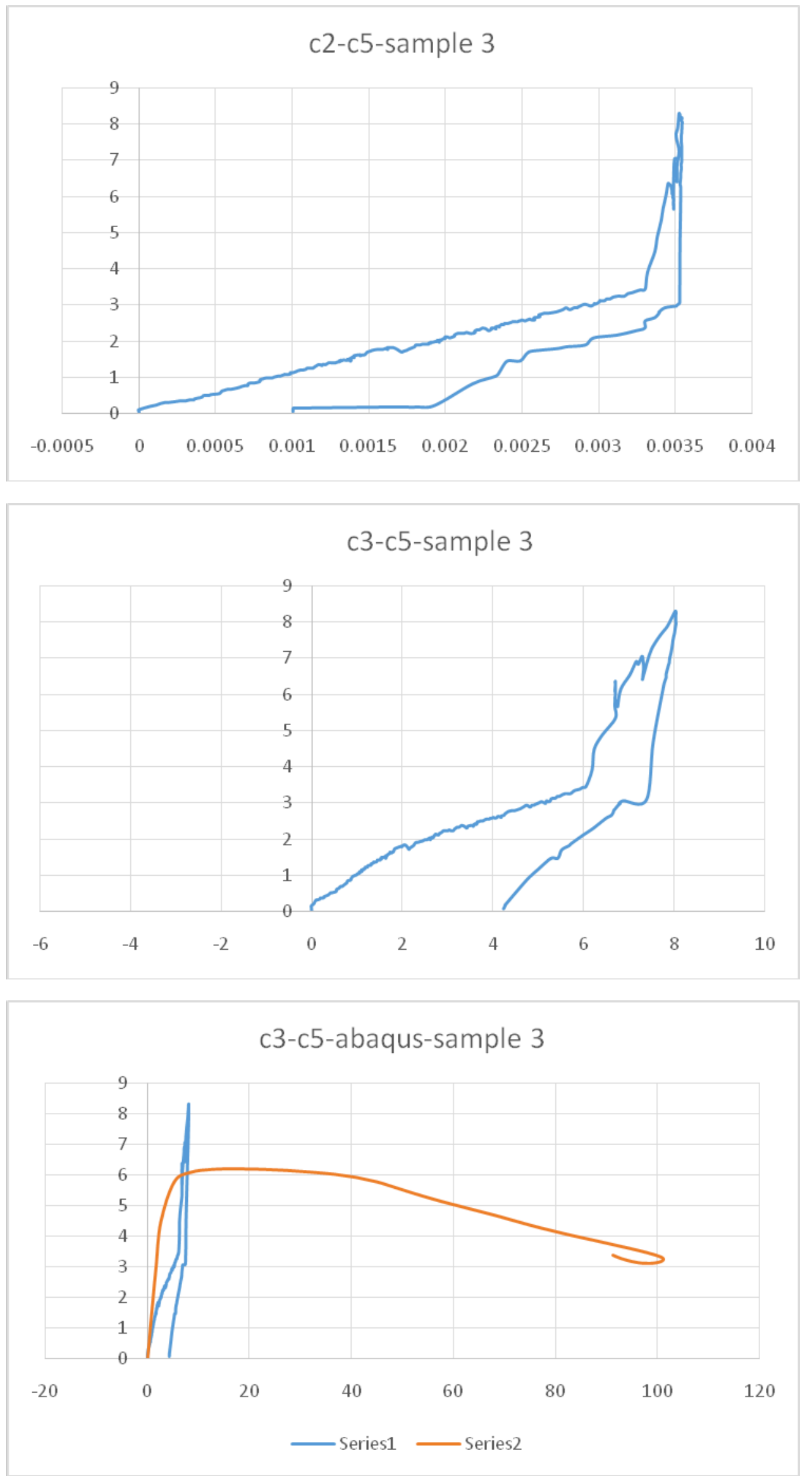
The Turkish Online Journal of Design, Art and Communication - TOJDAC July 2016 Special Edition
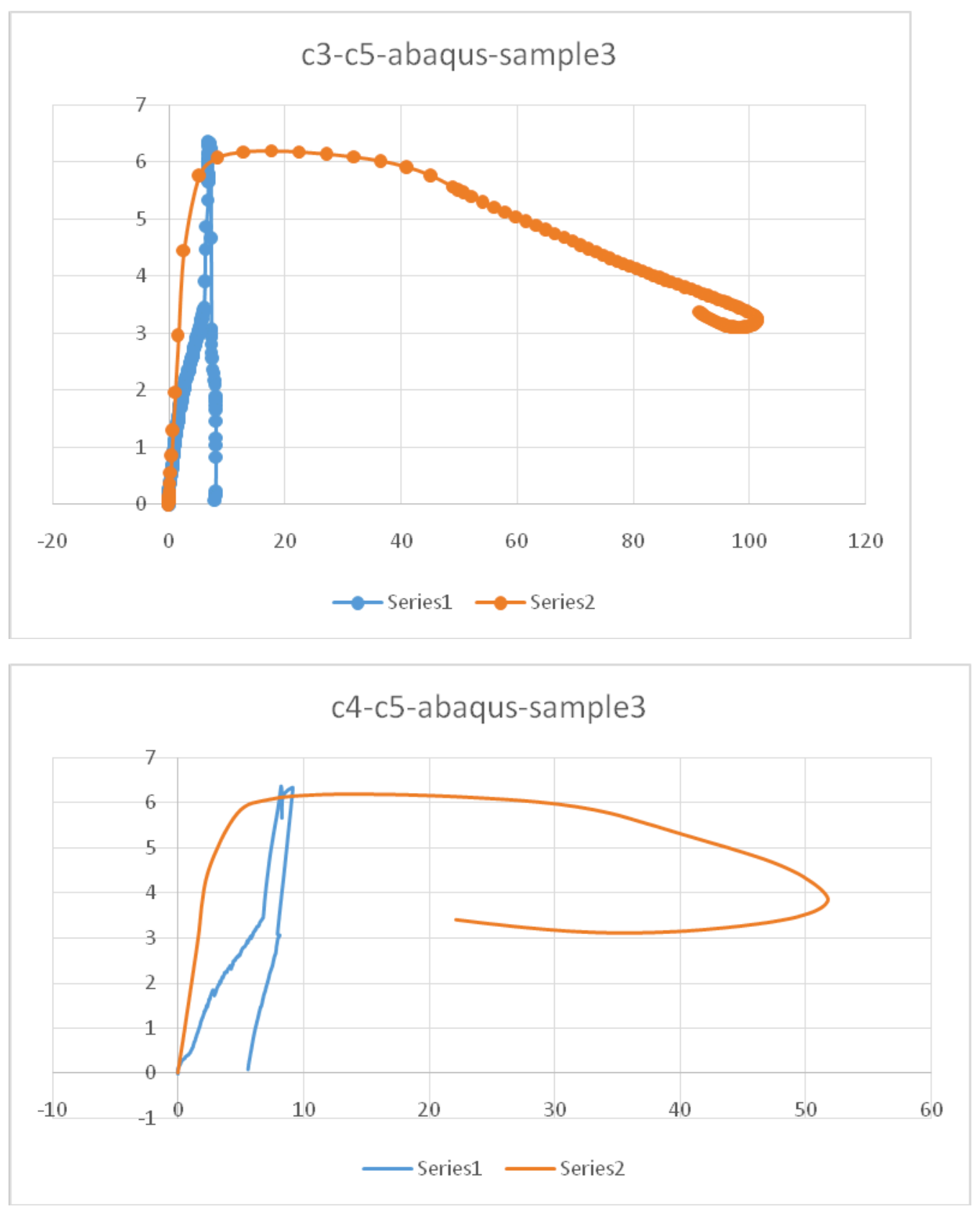

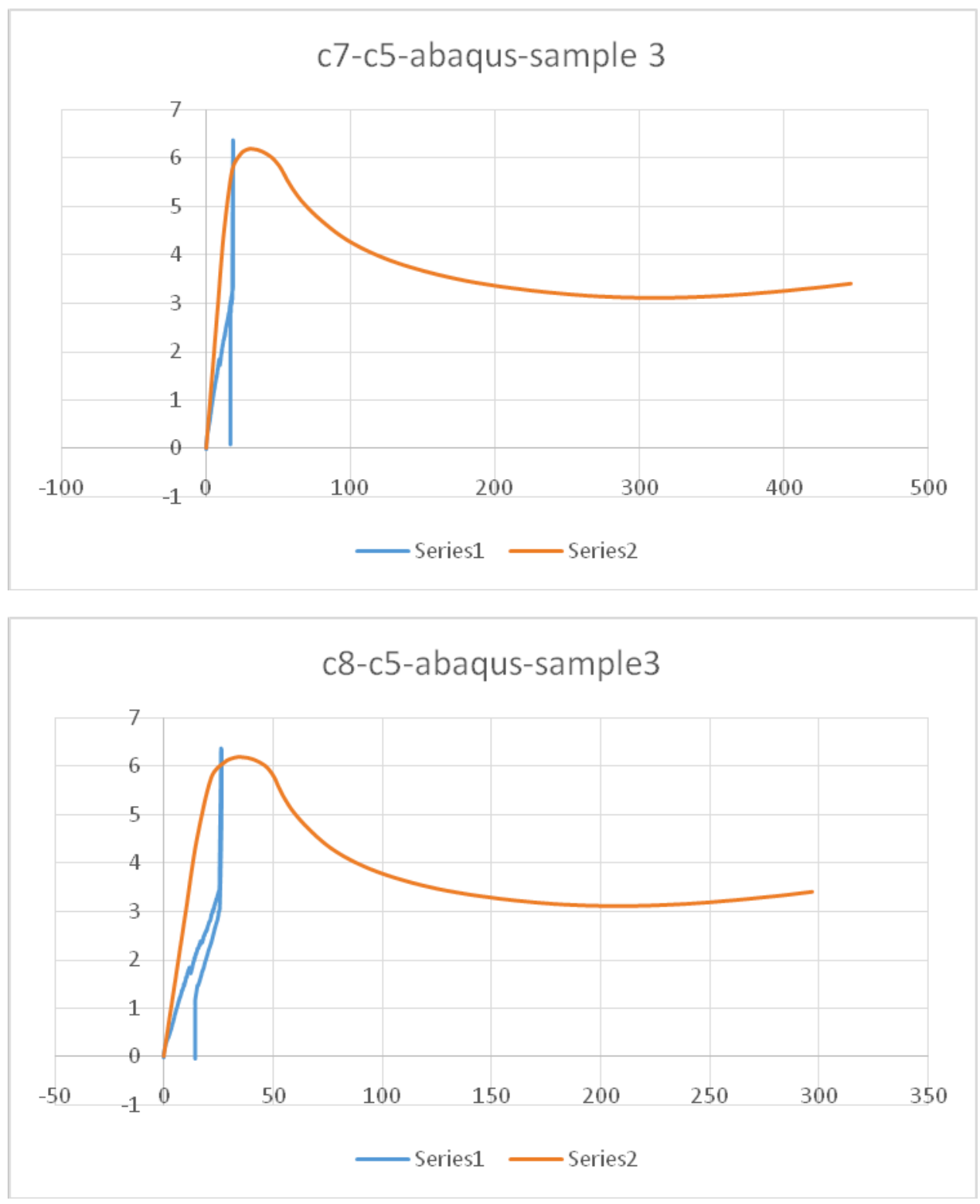

\section{CONCLUSION}

Of tests on the three samples, it was concluded that the use of lateral torsional buckling point, Delta strengthens the profile and prevent. And the result will be that much lower level, strengthening Delta in the quarter compared to the height of the life at half the delta boost is not life, it can be said that the state boost cross-section of the Delta in the quarter-height will be optimal.

\section{REFERENCES}

HOMER M. HADLEY, Consulting Engineer, Seattle," The Bridge Delta Girder Single-Webbed and Double-Webbed", AISC National Engineering Conference, Omaha, Nebr in May 1964.

HOMER M. HADLEY, Consulting Engineer, "Exploratory tests on a steel delta girder", Civil Engineering Magazine ,May 1961.

N.S. Trahair, "Flexural-Torsional Buckling of Structures", E \& FN SPON, Sydney,1993.

Zetlin L. Elastic instability of flat plates subjected to partial edge loads.In: Proceedings, ASCE 1955; 81(1): p. 795.

White RN, Cottingham WS. Stability of plates under partial edge loadings.In: Proceedings, ASCE 1962; 85(5): p. 6786 .

Rockey KC, Bagchi DK. Buckling of plate girder webs under partial edgeloadings. International Journal of Mechanics Science 1970;12:61_76. 